\title{
Promotion Strategies for Development of Agripreneurship in Rajasthan
}

\author{
Rajneesh $^{1 *}$, S. S. Sisodia ${ }^{1}$, F. L. Sharma ${ }^{1}$, Rajiv Bairathi ${ }^{1}$ and H. K. Jain ${ }^{2}$ \\ ${ }^{1}$ Department of Extension Education, RCA, Udaipur, India \\ ${ }^{2}$ Department of Statistics, RCA, Udaipur, India \\ *Corresponding author
}

\begin{abstract}
A B S T R A C T
Unemployment became big problem for country because of increasing population and less availability of jobs. In this situation entrepreneurship is only option that

can provide employment to people, government of India also promoting entrepreneurship by promoting different schemes and programmes. Present investigation is also based on entrepreneurship in agriculture field, in which researcher made an effort to present suggestions to promote and develop agripreneurship. This study was carried out in Rajasthan on agriculture graduates of three oldest and well established agriculture universities of Rajasthan and results of study represents that agripreneurship should be promoted by social system and government as important and respectful carrier option, quality of products should be superior and production should be in pace with quantity demanded in market, knowledge and education about policies, programmes and subsidies about agripreneurship should be provide to new entrepreneurs and agriculture graduates, legal formalities in establishment, loan, finance, certification of products should be less and easy an there is need to control corruption which is at every step were the major suggestions recommended by agriculture graduates for promotion of agripreneurship.
\end{abstract}

\section{Keywords}

Entrepreneurship, Agripreneurship,

Agriculture

graduates,

Suggestions,

Promotion

Article Info

Accepted:

15 February 2020

Available Online:

10 March 2020

\section{Introduction}

India is one of the fastest growing economy and most powerful countries of world with world's largest youth population. Country is developing in extraordinary way and achieving different records in many fields at global platform. But on other side India is overpopulated country with unavailability of employment to people and rising inflation in the prices that resulted as unsteady economy of country. So to overcome this adverse situation adoption of entrepreneurship is the ultimate option that can give self-employment to youth and improve the economic status of country by providing livelihood support. Small or large entrepreneurship has a pivotal role in Indian economy by creating business culture, job creation, economic growth, increasing national productivity, distribution 
of economic power, balancing regional development and by providing avenues for creativity and idea generation. Entrepreneurship is need of time, people and national economy. Government also making efforts to promote entrepreneurship and to encourage people for entrepreneurship. There are a lot of opportunities to harness with availability of many sectors. The present study is providing suggestions to promote agripreneurship sector. India is agriculture based country with having more than 65 per cent population of country how now related with agricultural activities and they are more familiar with agriculture, so starting entrepreneurship activities from agriculture will be more successful than any other sector. Agripreneurship can give different new dimensions to agriculture and can take at higher levels, agripreneurship have potential to make agriculture a main economic activity of country and agriculture can become main economic activities sector of country.

\section{Materials and Methods}

The present study was carried out in Rajasthan to collect the suggestions for promotion and development of entrepreneurship from 180 agriculture graduates randomly selected from three oldest and well established agriculture universities of Rajasthan namely M.P.U.A.T., Udaipur, S.K.R.A.U., Bikaner and S.K.N.A.U., Jobner. The suggestions were collected through well prepared schedule, reliability of which was ensured by calculating reliability coefficient (0.77) through split half method. Collected information was statistically analysed by using appropriate statistical parameters and results are presented in organised format.

\section{Results and Discussion}

Agriculture is the back bone of Indian economy. Agriculture research and education sector is also developing day by day and producing a very high number of agriculture graduates and post graduates but job and employment opportunities are not increasing. So, now it is time to focus on agripreneurship. Graduates in agriculture education are the individuals with good knowledge of agriculture. Agriculture graduates were asked to give suggestions for making agripreneurship more gainful, respectful and fulltime job provider activity. The obtained suggestions were analysed and presented.

\section{Suggestions for establishment of agri- enterprise}

Agriculture graduates provided suggestions based on their knowledge and experience gained during graduation for establishment of agri-enterprise. Analysis of data represents that "Agripreneurship should be promoted as a career by government and education institute" with MPS 100 was the suggestion provided by all the agriculture graduates and assigned first rank. Highest rank represents that suggestion was provided by highest number of agriculture graduates and viceversa. Rank II was assigned to "Educate new entrepreneurs about different policies, programmes and subsidies related to entrepreneurship" that will be helpful to increase the adoption of agripreneurship with MPS 96.11.

Rank III was assigned to "Rural entrepreneurs should be provided adequate and timely financial assistance from finance institutions" with MPS 95.00 that fulfil the requirement of fund and helps to establish agri-enterprise. Rank IV, V, VI, VII, VIII, IX and X were assigned to "Present education system should develop time management capacity in students", "Government should simplify its policies for agripreneurship", "Present education system should provide specialization in agripreneurship", 
"Entrepreneur development cell should be established at university or district level to coordinate between different agencies for assisting entrepreneurs", "Present education system should develop initiative taking ability", "Present education system should develop risk taking ability" and "Present education system should develop creativity and innovativeness" with MPS 93.89, 92.78, $91.67,86.11,85.00,82.78$ and 71.67, respectively. Last rank XI was assigned to "Present education system should develop problem solving attitude" with MPS 66.11. Most of the agriculture graduates recommended that education system has important role in development of all the qualities in a student to become a successful entrepreneur to establish and manage his agrienterprise successfully.

\section{Suggestions for financial and infrastructure issues of agripreneurship}

Finance is the basic requirement of any business, sometime if capital not available in time then it will become a serious problem for agripreneur. Other problems like nonavailability in required quantity, high rate of interest, non-availability of infrastructure, etc., were the suggestions provided by agriculture graduates to overcome financial and infrastructure problems.

The decreasing order of MPS of all the suggestions provided by agriculture graduates were like 95.56, 57.22, 38.33 and 35.00 for which ranks I, II, III and IV were assigned for suggestions "Formalities in sanctioning loan should be less and quick", "Government should provide relaxation in taxes for early period for newly established agri enterprise", "Government should provide infrastructure facilities like- land, electricity, water, road, warehouse and storage houses etc. on subsidized rate" and "Creation of separate finance cell at finance institutions and banks for entrepreneurship".
Suggestions related to management and technical issues of agripreneurship

Agriculture graduates based on their knowledge and experience from exposure to different agri-enterprises during educational tour, practical classes, RAWEP (Rural Agriculture Work Experience Programme) and industrial linkage programmes, provided some suggestions to overcome management and technical problems usually arise in agripreneurship.

Out of all recommendations "Agriculture graduates should be encouraged by exposed to various entrepreneurship development and supporting institutions" with MPS 92.78 was the mostly recommended suggestion by most of graduates and ranked first on the basis of highest MPS, successive ranks were allotted to next value of MPS in decreasing order. Rank II, III, IV, V, VI and VII was assigned to "Present education system should provide knowledge for commercial and legal aspects of business", "Government should organise exhibition and fairs for entrepreneur and markets for promotion of agripreneurship", "Agriculture graduates should be offered high quality training facilities, work shop, seminar and tour to improve their skill", "Agriculture graduates should be exposed to modern technologies", "Agriculture graduates should be encouraged by exposing them to various agri-enterprise", "Agriculture graduates should have knowledge of latest packaging material" with MPS 87.22, 85.56, 85.00, $84.44,63.89$ and 63.33, respectively.

\section{Marketing related suggestions for agripreneurship}

Marketing is the main activity of any business. It includes most of the problems of business like competition, fluctuation in demand, supply and price of products etc. 
Table.1 Suggestion related to establishment of agri enterprise

\begin{tabular}{|c|c|c|c|}
\hline & & & $=180$ \\
\hline S.No. & Suggestion related to establishment of agri enterprise & MPS & Rank \\
\hline 1 & $\begin{array}{l}\text { Agripreneurship should be promoted as a career by government and } \\
\text { education institutes }\end{array}$ & 100.00 & I \\
\hline 2 & $\begin{array}{l}\text { Educate new entrepreneurs about different policies, programmes and } \\
\text { subsidies related to entrepreneurship }\end{array}$ & 96.11 & II \\
\hline 3 & $\begin{array}{l}\text { Rural entrepreneurs should be provided adequate and timely financial } \\
\text { assistance from finance institutions }\end{array}$ & 95.00 & III \\
\hline 4 & Present education system should develop creativity and innovativeness & 71.67 & $\mathrm{X}$ \\
\hline 5 & Present education system should develop initiative taking ability & 85.00 & VIII \\
\hline 6 & Present education system should develop problem solving attitude & 66.11 & XI \\
\hline 7 & Present education system should develop risk taking ability & 82.78 & IX \\
\hline 8 & $\begin{array}{l}\text { Present education system should develop time management capacity in } \\
\text { students }\end{array}$ & 93.89 & IV \\
\hline 9 & $\begin{array}{l}\text { Entrepreneur development cell should be establish at university or } \\
\text { district level to co-ordinate between different agencies for assisting } \\
\text { entrepreneurs }\end{array}$ & 86.11 & VII \\
\hline 10 & $\begin{array}{l}\text { Present education system should provide specialization in } \\
\text { agripreneurship }\end{array}$ & 91.67 & VI \\
\hline 11 & Government should simplify its policies for agripreneurship & 92.78 & $\mathrm{~V}$ \\
\hline MPS - & Mean Per cent Score & & \\
\hline
\end{tabular}

Table.2 Suggestions related to financial and infrastructure issues of agripreneurship

\begin{tabular}{|l|l|c|c|}
\hline \multicolumn{2}{|l|}{} & \multicolumn{2}{|c|}{ n 180 } \\
\hline S.No. & Suggestions related to financial and infrastructure issues & MPS & Rank \\
\hline $\mathbf{1}$ & Formalities in sanctioning loan should be less and quick & 95.56 & I \\
\hline $\mathbf{2}$ & $\begin{array}{l}\text { Government should provide relaxation in taxes for early period for } \\
\text { newly established agri enterprise }\end{array}$ & 57.22 & II \\
\hline $\mathbf{3}$ & $\begin{array}{l}\text { Creation of separate finance cell at financial institutes and banks } \\
\text { for entrepreneurship }\end{array}$ & 35.00 & IV \\
\hline $\mathbf{4}$ & $\begin{array}{l}\text { Government should provide infrastructure facilities like- land, } \\
\text { electricity, water, road, warehouse and storage houses etc. on } \\
\text { subsidized rate }\end{array}$ & 38.33 & III \\
\hline MPS - Mean Per cent Score & & \\
\hline
\end{tabular}


Table.3 Suggestions related to management and technical issues for successful running of agri enterprise

\begin{tabular}{|c|c|c|c|}
\hline & & & $=180$ \\
\hline S.No. & Suggestion related to management and technical issues & MPS & Rank \\
\hline 1 & $\begin{array}{l}\text { Government should organise exhibition and fairs for entrepreneur and } \\
\text { markets for promotion of agripreneurship }\end{array}$ & 85.56 & III \\
\hline 2 & Agriculture graduates should be exposed to modern technologies & 84.44 & V \\
\hline 3 & $\begin{array}{l}\text { Agriculture graduates should be offered high quality training facilities, } \\
\text { work shop, seminar and tour to improve their skill }\end{array}$ & 85.00 & IV \\
\hline 4 & $\begin{array}{l}\text { Agriculture graduates should be encouraged by exposing them to } \\
\text { various agri-enterprise }\end{array}$ & 63.89 & VI \\
\hline 5 & $\begin{array}{l}\text { Agriculture graduates should be encouraged by exposed to various } \\
\text { entrepreneurship development and supporting institutions }\end{array}$ & 92.78 & I \\
\hline 6 & $\begin{array}{l}\text { Agriculture graduates should have knowledge of latest packaging } \\
\text { material }\end{array}$ & 63.33 & VII \\
\hline 7 & $\begin{array}{l}\text { Present education system should provide knowledge for commercial and } \\
\text { legal aspects of business }\end{array}$ & 87.22 & II \\
\hline
\end{tabular}

Table.4 Marketing related suggestions suggested by agrigraduates

\begin{tabular}{|l|l|c|c|}
\hline S.No. & Suggestions related to marketing issues & MPS & Rank \\
\hline $\mathbf{1}$ & $\begin{array}{l}\text { Establishing marketing co-operative that provide market information and } \\
\text { help entrepreneurs to sale their products }\end{array}$ & 36.67 & IV \\
\hline $\mathbf{2}$ & $\begin{array}{l}\text { Government should provide awareness about marketing programmes, } \\
\text { export and import }\end{array}$ & 81.11 & II \\
\hline $\mathbf{3}$ & $\begin{array}{l}\text { Entrepreneur should design his product according to market demand and } \\
\text { interest of customers }\end{array}$ & 72.78 & III \\
\hline $\mathbf{4}$ & $\begin{array}{l}\text { Quality and quantity of agri products and by-products are require to be } \\
\text { competitive and efficient in local and international market }\end{array}$ & 97.22 & I \\
\hline MPS - Mean Per cent Score & & \\
\hline
\end{tabular}

To overcome marketing problems agriculture graduates have provided some suggestions out of which "Quality and quantity of agri products and by-products are require to be competitive and efficient in local and international market" with MPS 97.22 was of most important as it is related with quality of products that should be of prime importance, the next II, III and last IV rank was assigned to suggestions like "Government should provide awareness about marketing programmes, export and import", "Entrepreneur should design his product according to market demand and interest of customers" and "Establishing marketing cooperative that provides market information and help entrepreneurs to sale their products" with MPS 81.11, 72.78 and 36.67, respectively. 
To conclude the study of all suggestions provided for each section of entrepreneurship, highly recommended suggestions on the basis of analysis are "Agripreneurship should be promoted as a career by government and education institute" was the most important suggestion because without basic training of agripreneurship graduates cannot be motivated to adopt agripreneurship as an occupation for their life. Second suggestion "Quality and quantity of agri products and byproducts are require to be competitive and efficient in local and international market" only superior quality can leads to success because the product is only the thing which has to select or reject by its customers that reflects as success or failure of that particular enterprise. Third suggestion "Educate new entrepreneurs about different policies, programmes and subsidies related to entrepreneurship" recommends to increase the knowledge of agrigraduates which can create positive attitude and environment that will encourage the graduates to adopt the agripreneurship. The suggestions "Formalities in sanctioning loan should be less and quick" and "Rural entrepreneurs should be provided adequate and timely financial assistance from all finance institutions" represents that capital is prime requirement to run any business and timely availability and supply of capital ensure the proper management of all the activities of agripreneurship. Suggestions "Present education system should develop time management capacity in students", "Present education system should provide specialization in agripreneurship", "Present education system should provide knowledge for commercial and legal aspects of business" were made the recommendations to education system because education system has main role in constructing the attitude of students towards some activities, specially agriculture education institutes have to come forward and have to put extra efforts for development of agripreneurship through development of all basic qualities of entrepreneur in students, provide all the knowledge related to every aspect like production, processing, value addition, marketing, technical, commercial, social and legal etc. related to agripreneurship. Education system has to provide all the technical knowledge and how now, technical skills, practical knowledge and real time experience through exposure and visit to different agri-enterprises, organising special trainings, workshop activities, guest lectures, success stories, etc. The suggestions "Government should simplify its policies for agripreneurship" and "Agriculture graduates should be exposed to various entrepreneurship development and supporting institutions" made recommendation to government for creating a favourable and positive environment for agripreneurship by simplifying the rules and regulations and by creating awareness and providing knowledge through exposing rural youth and agriculture graduates to successful enterprises that will encourage them to adopt agripreneurship as occupation and to solve the problem of unemployment by proving a chance to becoming job provider.

\section{References}

Azizi, B., Hosseini, J. F., Mahmood, H. and Mirdamadi, M. 2010. Factors influencing the development of entrepreneurial education in Iran's applied-scientific educational centres for agriculture. American Journal of Agricultural and Biological Sciences. 5(1): 77-83.

Shiri, N., Alibaygi, A. and Faghiri, M. 2013. Factors affecting entrepreneurial motivation of agricultural students at Razi University. International Journal of Agricultural Management and Development.3(3): $\quad$ 175-180. www.ijamad.com.

Emerole, C. O., Dorcas, U., and Kelechi, C. 
2014. Determinants of entrepreneurship decision for agricultural business among graduates in Abia State, Nigeria. International Conference on Agricultural, Environmental and Biological Sciences, Phuket (Thailand). Pp. 5-10. http://dx.doi.org/10.15242/IICBE.C414 014.

Omotesho, K. F., Olabode, D. A., Animashaun, J. O. and Ogunlade, I. 2015. Knowledge and attitude of agriculture students towards commercialization of date palm in university of Ilorin, Nigeria. Journal of Research in Forestry, Wildlife and Environment. 7(2): 91-102.

Shivacharan, G., V. Sudha Rani and Vasantha, R. 2017. Rural young agri entrepreneurs: problems, suggestions and strategy for successful running of their enterprise. International Journal of Current Microbiology and Applied Sciences. $\quad 6(11):$ 259-264. https://doi.org/10.20546/ijcmas.2017.61 1.031 .
Amadi, N. S. and Nnodim, A. U. 2018. Role of agricultural education skills in entrepreneurship development in Rivers state. International Journal of Innovative Social \& Science Education Research. 6(1):9-18.

Nwokolo, E. E. 2018. Curbing Unemployment Challenges among University Graduates through Entrepreneurship Education and Training in South Africa. Journal of Social Science. 54(1): 22-30.

Ramesh N., Sagar M. P., Tiwari R., Pachaiyappan K. and Balaraju B. L. 2018. Career preferences of agriculture and animal sciences undergraduates. International Journal of Livestock Research. 8(4): 195-201.

Shuaibu, H., Jogana, M. A., and Mukhtar, N. 2018. Integrating entrepreneurship and technical education as a panacea for graduates unemployment in Nigeria. British Journal of Education. European Centrefor Research Training and Development UK.www.eajournals.org. 6(3):57-71.

\section{How to cite this article:}

Rajneesh, S. S. Sisodia, F. L. Sharma, Rajiv Bairathi and Jain, H. K. 2020. Promotion Strategies for Development of Agripreneurship in Rajasthan. Int.J.Curr.Microbiol.App.Sci. 9(03): 2167-2173. doi: https://doi.org/10.20546/ijcmas.2020.903.248 